Tersedia online di:http://ejournal-balitbang.kkp.go.id/index.php/jkpi
e-mail:jkpi.puslitbangkan@gmail.com
JURNAL KEBIJAKANPERIKANANINDONESIA
Volume 12 Nomor 1 Mei 2020
p-ISSN: 1979-6366
e-ISSN: 2502-6550
Nomor Akreditasi Kementerian RISTEKDIKTI: 21/E/KPT/2018

\title{
STATUS PEMANFAATAN DAN UPAYA PENANGANAN HIU PAUS (Rhincodon typus) TERDAMPAR DI PERAIRAN INDONESIA
}

\section{THE UTILIZATION STATUS AND HANDLING EFFORT FOR WHALE SHARKS (Rhincodon typus) STRANDED IN INDONESIAN WATERS}

\author{
Budi Nugraha*1, Dharmadi dan Ngurah N. Wiadnyana' \\ ${ }^{1}$ Pusat Riset Perikanan, JI. Pasir Putih II, Ancol Timur, Jakarta Utara-14430, Indonesia \\ Teregistrasi I tanggal: 13 Desember 2019; Diterima setelah perbaikan tanggal: 02 Juli 2020; \\ Disetujui terbit tanggal: 16 Juli 2020
}

\begin{abstract}
ABSTRAK
Hiu paus merupakan salah satu jenis hiu berukuran terbesar yang ada di dunia dan sudah masuk dalam daftar merah (Red List) untuk spesies terancam IUCN yaitu berstatus terancam punah (endangered). Untuk menjaga agar sumber daya hiu paus tetap terjamin populasinya, maka perlu adanya upaya pengelolaan untuk mendukung pelestarian spesies ini. Dalam makalah ini dibahas tentang strategi pemanfaatan dan penanganan hiu paus yang terdampar di perairan Indonesia. Metode penelitian yang digunakan adalah survei lapang dan wawancara yang dilakukan di Probolinggo dan Situbondo, Jawa Timur. Data dan informasi dihimpun dari penelusuran, dan penelahaan data dan informasi hasil penelitian serta laporan kegiatan yang terkait dengan hiu paus terdampar maupun keberadaannya di beberapa wilayah perairan di Indonesia. Hasil kajian menunjukkan bahwa terdapat enam wilayah perairan kemunculan hiu paus di Indonesia, baik yang menetap maupun yang tinggal sementara yaitu di perairan Teluk Cendrawasih, Talisayan, Kaimana, Teluk Gorontalo, Probolinggo, dan Banggai Kepulauan. Jumlah hiu paus yang berada di perairan Indonesia dan tersebar di beberapa wilayah perairan diperkirakan mencapai 253 ekor. dan teramati terbanyak berada di perairan Teluk Cendrawasih sebanyak 131 ekor. Kemunculan hiu paus maupun yang terdampar hampir terjadi setiap tahun dalam kondisi hidup terkadang keadaan mati. Koordinasi antara instansi terkait dan masyarakat dalam menangani dan menyelamatkan hiu paus yang terdampar maupun terjerat jaring saat ini sudah berjalan dengan baik. Terdapat 7 tahapan tata cara penanganan hiu paus terdampar dan ada 4 tahapan dalam rangka menunjang ekowisata hiu paus.
\end{abstract}

\section{Kata Kunci: Pemanfaatan; penanganan; hiu paus; perairan Indonesia}

\begin{abstract}
Whale shark is one of the largest sharks in the world and on the red list IUCN for endangered species. To ensure that the population of whale sharks remains guaranteed, management efforts are needed to support the conservation of this species. The utilization and handling strategy of the whale sharks that stranded down in several Indonesian waters should be discussed seriously. Field survey method was applied and interview was done in Probolinggo and Situbondo, East Java. Data and information were collected and had been analyzed as well as activities reported that related to whale sharks stranded and their presence in several territorial waters Indonesia waters. The results of the study showed that there were six Indonesia waters area in which whale sharks appeared, both permanent and temporary, namely in Cendrawasih Bay, Talisayan, Kaimana, Gorontalo, Probolinggo, and Banggai Islands. The whale shark number that found in several Indonesian waters had been estimated about 253 individuals and the highest number was found 131 in Cendrawasih Bay. The appearances of whale shark and stranded in Indonesian waters has been almost every year and found in living or in such cases been in dead conditions that trapped in the shallow area. Coordination between related agencies and the community to carry out and rescuing whale sharks stranded or entangled in nets, has been in good progress. There were 7 stages of procedures for handling
\end{abstract}


stranded whale sharks and 4 stages in order to support the ecotourism activities that related with appearances of whale sharks.

\section{Keywords: Utilization; handling; whale sharks; Indonesian waters}

\section{PENDAHULUAN}

Hiu paus (Rhincodon typus) merupakan salah satu jenis hiu terbesar dari 509 jenis hiu yang ada di dunia (Weigmann, 2016) dan bermigrasi jauh (Brunnschweiler et al., 2009; Eckert \& Stewart, 2001) serta lebih banyak menghabiskan waktunya di kolom air dekat permukaan (Colman,1997). Hiu paus mempunyai sebaran habitat geografis yang luas di perairan tropis dengan suhu air yang hangat (McKinney et al., 2012; White \& Cavanagh, 2007) dan diketahui beragregasi secara musiman dekat pantai dan sepanjang terumbu karang di perairan tropis dan subtropis di seluruh dunia (Stewart \& Wilson, 2005), biasanya didominasi oleh fase juvenil dan remaja jantan (Riley et al., 2010; Brooks et al., 2010; Rowat et al., 2011). Selain di perairan Indonesia, beberapa perairan yang sering menjadi tempat munculnya hius paus secara musiman diantaranya adalah di perairan Ningaloo Reef, Australia (Taylor, 1996), Belize (Heyman et al., 2001), Seychelles (Rowat \& Gore, 2007), Maldives (Anderson \& Ahmed, 1993), dan Mexico (de la Parra Venegas et al., 2011; Ketchum et al., 2012; Hueter et al., 2013) serta Qatar (Robinson et al., 2013).

Sejak tahun 1999, hiu paus masuk dalam daftar merah/Red List International Union for Conservation of Nature (IUCN) yaitu berstatus terancam punah (endangered) yang mana populasinya sudah mengalami penurunan diperkirakan sebesar $40-92 \%$ (Pierce \& Norman, 2016). Oleh karena itu, sebanyak 26 negara (tidak termasuk Indonesia) telah mendatangani MoU untuk sepakat melindungi spesies tersebut. Namun demikian, Indonesia sangat mendukung langkah tersebut yakni dengan mengeluarkan surat Keputusan Menteri Kelautan dan Perikanan RI No. 18/KEPMEN-KP/2013 untuk perlindungan hiu paus secara penuh, yang artinya bahwa hiu paus dan produk olahannya dilarang dimanfaatkan dan diperdagangkan di Indonesia.

Setelah diberlakukannya perlindungan penuh terhadap keberadaan hiu paus, banyak pemerhati konservasi biota laut baik nasional maupun internasional yang memberikan perhatian khusus terhadap aksi pengelolaannya di Indonesia. Untuk menjaga agar sumber daya hiu paus tetap terjamin populasinya, perlu adanya upaya pengelolaan untuk mendukung pelestarian spesies ini. Hiu paus, pada kondisi sekarang, banyak dimanfaatkan sebagai obyek wisata laut melalui kemunculannya di permukaan air. Agar pemanfaatan hiu paus ini tidak mengganggu keberadaan populasinya di perairan Indonesia, maka diperlukan adanya strategi pemanfaatan yang tepat. Begitu pula dengan kasus terdamparnya hiu paus yang dapat menyebabkan kematian, perlu adanya upaya-upaya penanganan agar tidak menyebabkan hiu paus tersebut mati sehingga dapat dikembalikan ke laut dalam kondisi hidup. Dalam tulisan ini dibahas tentang status pemanfaatan dan upaya penanganan hiu paus yang terdampar di perairan Indonesia. Data dan informasi sekunder dihimpun dan ditelusuri serta ditelaah dari hasil penelitian yang telah dilakukan serta laporan kegiatan dari berbagai sumber yang terkait dengan terdamparnya hiu paus maupun keberadaannya di beberapa wilayah perairan di Indonesia.

\section{DAERAH PENYEBARAN DAN BANYAKNYA HIU PAUS DI INDONESIA}

Beberapa lokasi yang teridentifikasi sebagai habitat tetap ataupun sementara (temporary) dan kawasan agregasi hiu paus di permukaan secara berkala di Indonesia antara lain: perairan Teluk Cendrawasih, Kaimana, Nabire, Maluku Utara, Gorontalo, Talisayan, Probolinggo, Laut Sawu dan Anambas (Himawan et al., 2015). Menetapnya sub populasi hiu paus di perairan tersebut diduga berkaitan dengan ketersediaan makanan dan kondisi hidrografi yang sesuai untuk kelangsungan hidupnya. Berdasarkan hasil pengumpulan dan integrasi data (Himawan et al., 2017), sub populasi hiu paus di beberapa perairan disajikan dalam Tabel 1 . Sementara jumlah individu hiu paus teramati di kawasan agregasi di beberapa perairan Indonesia tersaji pada Tabel 2 dan Gambar 1. Sub populasi hiu paus di perairan Teluk Cendrawasih berdasarkan hasil pengamatan sebelum dan sesudah diberlakukannya perlindungan penuh, namun sub populasi hiu paus untuk beberapa wilayah perairan lainnya berdasarkan hasil pengamatan setelah bersatus perlindungan penuh.

Keberadaan kelompok hiu paus di beberapa perairan di Indonesia diduga berkaitan dengan kondisi lingkungan perairan, topografi laut, dan keberadaan kelompok ikan-ikan pelagis kecil sebagai makanannya. Seperti halnya kemunculan hiu paus di perairan Probolinggo diduga sangat dipengaruhi oleh faktor kedalaman perairan (9-14 m), disusul oleh ketersediaan makanan $\left(0,5-0,9 \mathrm{mg} / \mathrm{m}^{3}\right)$ dan suhu permukaan laut $\left(29-30^{\circ} \mathrm{C}\right)$ (Syah et al., 2018). 
Tabel 1. Banyaknya sub populasi hiu paus di beberapa wilayah perairan di Indonesia

Table 1. Sub population number of whale sharks in some Indonesian waters

\begin{tabular}{llc}
\hline \multicolumn{1}{c}{$\begin{array}{c}\text { Wilayah Perairan } \\
\text { Waters Area }\end{array}$} & $\begin{array}{c}\text { Banyaknya (ekor) } \\
\text { Number (individual) }\end{array}$ \\
\hline 1. & Teluk Cendrawasih & 131 \\
2. & Talisayan & 34 \\
3. Kaimana & 20 \\
4. Gorontalo & 20 \\
5. Probolinggo & Total & 28 \\
\hline & & $\mathbf{2 3 3}$ \\
\hline
\end{tabular}

Sumber: Himawan et al. (2017)

Tabel 2. Jumlah individu hiu paus teramati di kawasan agregasi di beberapa perairan Indonesia

Table 2. Number of individual whale sharks that been observed in aggregation areas at several Indonesian waters

\begin{tabular}{lccc}
\hline $\begin{array}{c}\text { Wilayah Perairan } \\
\text { Waters Area }\end{array}$ & $\begin{array}{c}\text { Banyaknya } \\
\text { (ekor) } \\
\text { Number } \\
\text { (individual) }\end{array}$ & $\begin{array}{c}\text { Tahun Pengamatan } \\
\text { Year of Observation }\end{array}$ & $\begin{array}{c}\text { Sumber } \\
\text { Sources }\end{array}$ \\
\hline Teluk Cendrawasih & 131 & $2010-2016$ & Tania et al. (2016) \\
Kaimana & 20 & $2014-2015$ & Hasan \& Sianipar (2019) \\
Laut Sawu & 7 & 2016 & Putra \& Lewis (2017). \\
Talisayan & 36 & $2014-2017$ & Himawan, (2017) \\
Botubarani & 20 & 2017 & Himawan, (2017) \\
Probolinggo & 28 & 2016 & Himawan, (2017) \\
Anambas & 11 & $2010-2016$ & Himawan et al. (2017) \\
\hline Total & $\mathbf{4}$ & \\
\hline
\end{tabular}

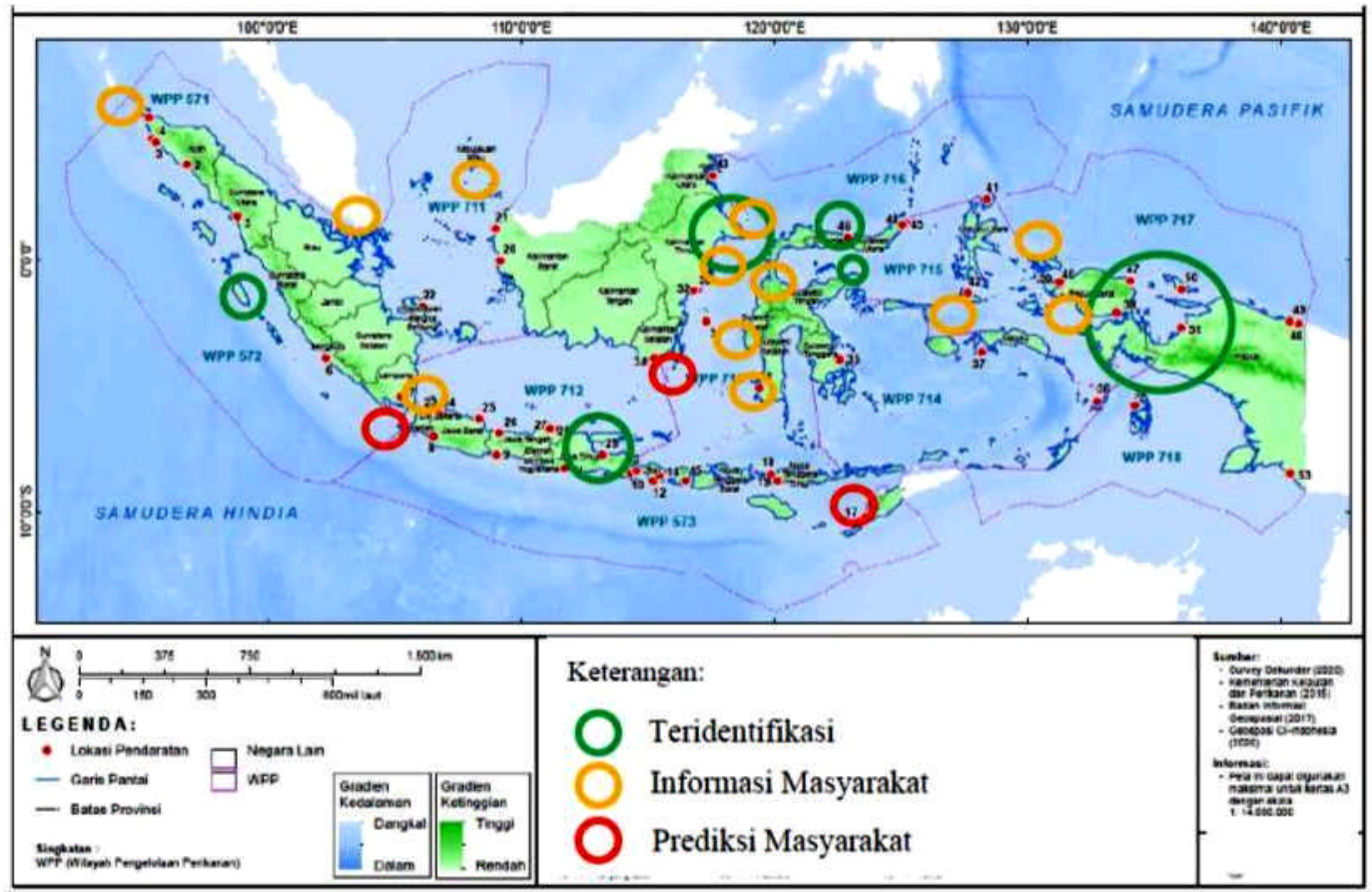

Gambar 1. Peta sebaran ditemukannya hiu paus di Indonesia (Sumber: Himawan et al., 2015).

Figure 1. Map of whale shark distribution that found in Indonesia (Source: Himawan et al., 2015).

Dari beberapa lokasi di Indonesia dimana terdapat kelompok hiu paus baik yang menetap maupun hanya tinggal sementara, hal ini diduga terdapat keterkaitan yang kuat antara keberadaan hiu paus dan kelimpahan plankton, yang juga sekaligus sebagai makanan ikan-ikan kecil yang juga dapat menarik 
kedatangan hiu paus untuk mencari makanannya di sekitar bagan. Selain plankton dan ikan-ikan kecil, makanan hiu paus diantaranya krill (sejenis udang kecil dari genus Euphausia), larva kepiting pantai, makro alga, dan fauna-fauna kecil nektonik seperti cumi-cumi ataupun verteberata kecil, hamburan jutaan telur ikan yang sudah difertilisasi yang melayanglayang di air laut selama musim memijah, serta memangsa ubur-ubur dan larva ikan kakap (Clarke \& Nelson, 1997; Wilson \& Newbound, 2001).

Himawan (2014) melaporkan bahwa salah satu faktor yang diduga mempengaruhi kemunculan hiu paus ialah hasil tangkapan nelayan bagan. Lebih lanjut dijelaskan bahwa hiu paus memiliki ketertarikan terhadap jumlah ikan kecil di perairan Teluk Cendrawasih yang dibuktikan dari perilaku naiknya hiu paus ke permukaan karena adanya ikan kecil di dalam jaring bagan di perairan Sowa dan Kwatisore serta Yaur. Beberapa contoh lokasi perairan di mana tercatat sub populasi hiu paus muncul dan teramati, yang dihubungkan dengan tingginya aktivitas perikanan bagan dan pembuangan hasil dari pengolahan udang seperti di Teluk Cendrawasih, perairan Talisayan (Kalimantan Timur), perairan Probolinggo (Jawa Timur) dan perairan Botubarani (Gorontalo). Sub populasi hiu paus di Teluk Cendrawasih dan perairan Talisayan teramati lebih dai $90 \%$ berjenis kelamin jantan (Gambar 2). Hasan \& Sianipar (2019), juga mengidentifikasi bahwa hiu paus yang muncul di perairan Kaimana didominasi oleh jantan. Salah satu hal generik yang telah diketahui tentang hiu paus di dunia adalah bahwa kebanyakan agregasi di dunia bersifat musiman, dan didominasi oleh individu jantan muda (Sianipar, 2019).

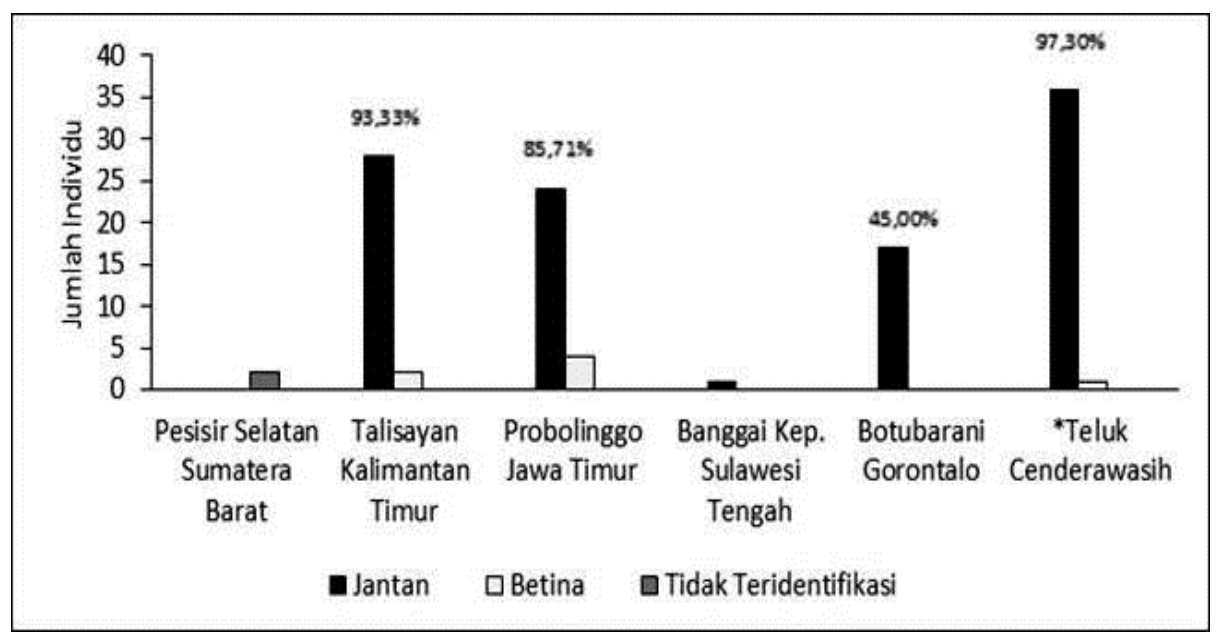

Gambar 2. Sub populasi dan komposisi jenis hiu paus yang teramati berdasarkan lokasi dan jenis kelaminnya (Sumber: Himawan, 2014).

Figure 2. Sub population and species composition of whale sharks were observed based on location and sex (Source: Himawan, 2014).

\section{KEMUNCULAN HIU PAUS}

Kemunculan hiu paus sering terjadi di berbagai lokasi di perairan Indonesia yang merupakan jalur migrasi hiu paus yang pada umumnya melakukan migrasi secara soliter dan sedikit yang berkelompok.
Kelompok hiu paus yang bermigrasi ke suatu perairan tertentu diduga kuat karena faktor adanya kelimpahan makanan di perairan tersebut (Tania \& Himawan, 2017). Kemunculan hiu paus di beberapa wilayah perairan Indonesia disajikan pada Gambar 3. 


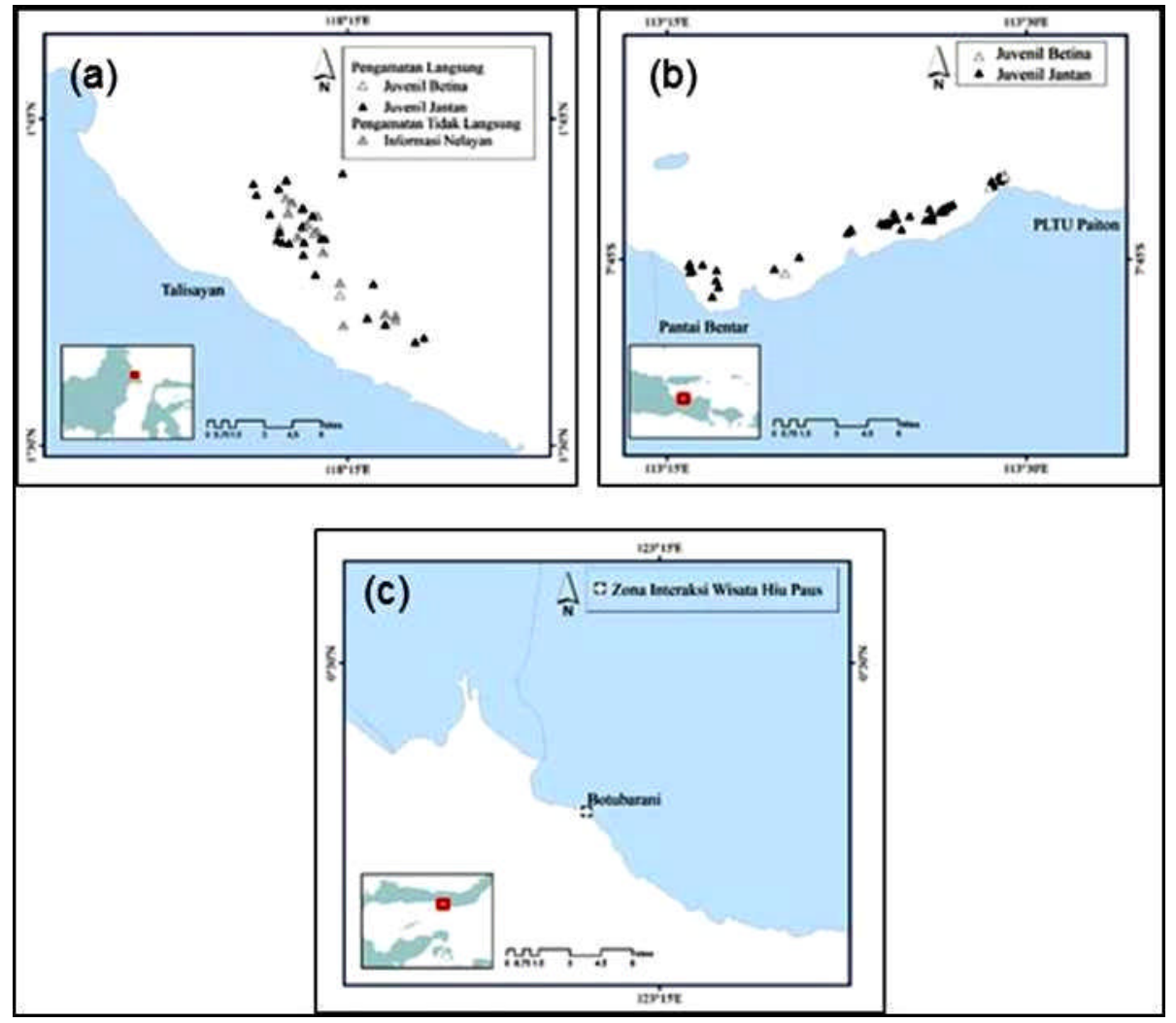

Gambar 3. Kemunculan hiu paus di perairan Talisayan (a), perairan Probolinggo dan Situbondo (b), dan perairan Botubarani-Gorontalo (c) (Sumber: Himawan, 2014).

Figure 3. The appearance of whale sharks in Talisayan waters (a), Probolinggo and Situbondo waters (b), and Botubarani-Gorontalo waters (Source: Himawan, 2014).

Kemunculan kelompok hiu paus di perairan Talisayan (Gambar 3a) menunjukkan dominansi jantan dari pada betina, namun keduanya masih dalam tingkat juvenil. Nampak bahwa hiu paus cenderung berkelompok. Kemunculan kelompok hiu paus di perairan Probolinggo (Gambar 3b) juga berkaitan dengan kelimpahan ikan-ikan pelagis di perairan tersebut. Berdasarkan informasi yang dihimpun, diketahui bahwa kemunculan hiu paus di sekitar perairan Probolinggo terjadi pada periode Mei-Juli dan Oktober-Desember, yang terjadi setiap tahun. Umumnya kemunculan hiu paus pada periode MeiJuli lebih banyak dan sering bergerombol dengan jumlah sekitar 20-30 individu dan didominasi oleh ukuran 2-3 m. Diduga hiu paus berukuran kecil ini merupakan anakan karena terdapat 2-3 individu berukuran besar sekitar $15-20 \mathrm{~m}$ yang diduga merupakan induknya.

Hasil penelitian Noviyanti et al. (2015), menunjukan bahwa hiu paus senantiasa muncul di perairan Probolinggo hampir setiap tahun antara bulan Desember-Maret. Pada periode Oktober-Desember meskipun terdapat kemunculan hiu paus, namun kemunculan ini jarang terjadi dan bila ada hanya berjumlah 1-2 individu saja. Hal ini diduga berkaitan dengan aktivitas hiu paus yang sedang melintas untuk melakukan migrasi. Kemunculan hiu paus yang rutin terjadi setiap tahun di perairan sekitar Probolinggo diduga berkaitan dengan sumber daya ikan pelagis yang tersedia sebagai makanannya. Di perairan ini sejak tahun 1990-an masyarakat nelayan sudah menggunakan bagan tancap untuk menangkap ikan. Saat ini diperkirakan terdapat 30 unit bagan tancap yang masih beroperasi di perairan Probolinggo. Diduga, adanya kegiatan perikanan bagan ini yang menyebabkan munculnya hiu paus.

Di perairan sekitar Situbondo yang lokasinya berdekatan dengan Probolinggo, hiu paus muncul di sekitar kawasan wisata Pasir Putih, namun hal ini sangat jarang terjadi. Kemunculan dalam jumlah kecil (1-2 individu) hanya berlangsung pada bulan Nopember setiap tahunnya. Diduga hal ini disebabkan karena di perairan sekitar Situbondo tidak terdapat kegiatan penangkapan ikan dengan menggunakan bagan.

Kemuculan hiu paus di perairan Botubarani tercatat dengan baik sejak 2016, saat itu terdapat pabrik pengolahan udang yang limbahnya terbuang ke laut. Ternyata limbah udang yang terbuang ke laut ini 
menarik kedatangan hiu paus sampai mendekati pinggiran laut (Handoko, et al., 2018). Dari informasi yang diperoleh melalui masyarakat setempat yang mengelola pariwisata hiu paus, diketahui bahwa hiu paus sampai 2018 muncul sepanjang tahun. Namun, setelah tidak beroperasinya lagi pabrik pengolahan udang di Pantai Botubarani, hiu paus semakin jarang mendatangi perairan pesisir Botubarani. Hal ini mengindikasikan ketertarikan hiu paus berenang dan muncul sampai ke perairan pesisir mendekati pantai karena faktor makanan. Dugaan ini diperkuat karena kondisi perairan tetap seperti semula sejak diketahuinya kemunculan hiu paus di sekitar perairan Botubarani sampai saat ini, kecuali tidak beroperasinya lagi pabrik pengolahan udang di lokasi itu. Dengan tidak adanya sumber makanan yang berasal dari limbah pabrik ini dikhawatirkan kedatangan hiu paus semakin lama terus berkurang sampai tidak ada lagi kemunculan hiu paus di perairan Botubarani. Untuk itu perlu adanya kajian agar kemunculan hiu paus di perairan ini dapat terus berlangsung, sebab kemunculan hiu paus di sekitar perairan Botubarani telah menjadikan lokasi ini sebagai obyek wisata bahari yang sudah terkelola oleh masyarakat setempat.

Pola distribusi hiu paus di perairan Indonesia sejauh ini diketahui secara horizontal. Namun hasil penelitian yang dilakukan di perairan Samudera Hindia menunjukkan distribusi juga terjadi secara vertikal di mana hiu paus mampu bergerak di antara tiga cekungan laut terbesar dengan total waktu perjalanan minimal sekitar 2-4 tahun (Squeira et al., 2013). Di Indonesia, penelitian pergerakan hiu paus dengan mengunakan tagging yang dihubungkan dengan citra satelit telah dilakukan oleh $\mathrm{Cl}$ Indonesia pada tahun 2016 di dua lokasi yaitu Teluk Cendrawasih dan perairan Kaimana (Hasan \& Sianipar, 2019; Sianipar 2019), namun penelitian masih berlangsung sehingga belum ada hasil yang dapat dilaporkan secara lengkap (Research in progress) selain rute pergerakan yang disajikan pada Gambar 4 (Himawan, 2014).

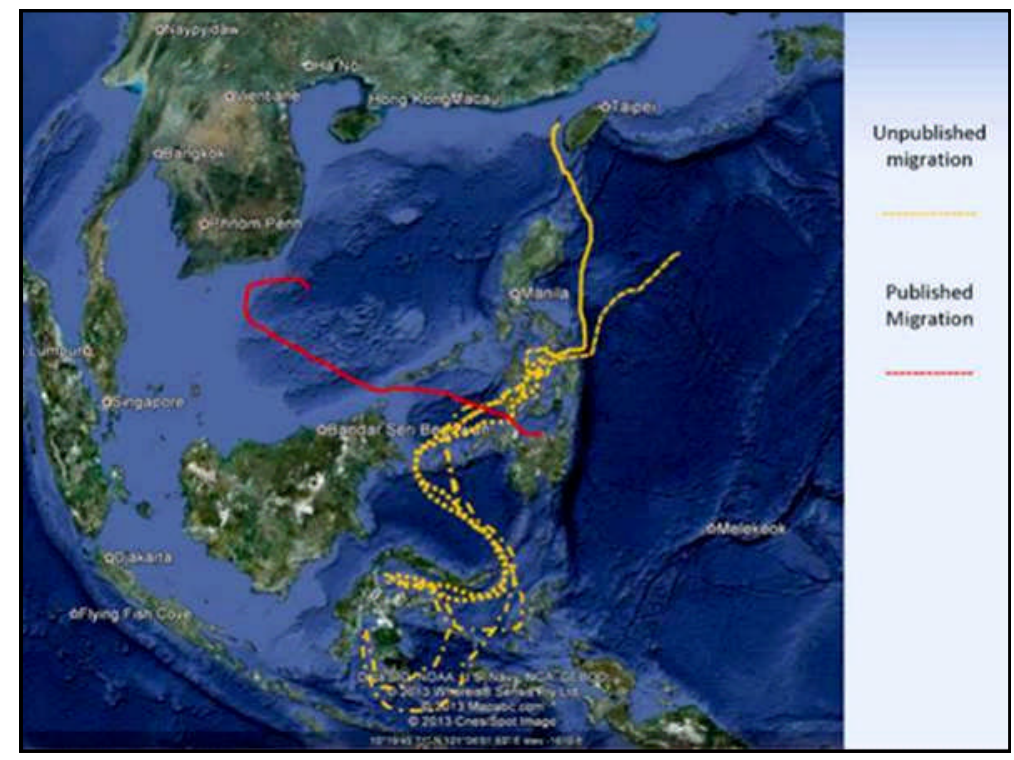

Gambar 4. Alur migrasi hiu paus di perairan Indonesia (Sumber: Himawan, 2014).

Figure 4. Migration pattern of whale sharks in Indonesian waters (Source: Himawan, 2014).

\section{KASUS HIU PAUS TERDAMPAR DAN TERJERAT JARING}

Fenomena terjadinya kematian hiu paus akibat terdampar dan atau terjerat jaring di perairan Indonesia merupakan isu yang perlu dikaji. Selain karena faktor ketersediaan makanan yang mengundang perhatian bagi sekelompok hiu paus bermigrasi dan melintasi perairan Indonesia juga diduga karena faktor perubahan iklim global. Namun untuk mengetahui kondisi perubahan iklim global dan kaitannya dengan pola migrasi hiu paus masih perlu dilakukan penelitian secara mendalam dengan melibatkan negara lain yang wilayah perairannya juga dilintasi oleh biota ini. Kasus terdamparnya hiu paus di beberapa lokasi perairan Indonesia terjadi setiap tahun pada periode berbeda. Pada periode 2009-2016, setidaknya telah tercatat 48 kejadian hiu paus terdampar mati dan hidup di perairan pesisir Indonesia. Dalam banyak kejadian, hiu paus akhirnya terdampar dan mati setelah sebelumnya tertangkap tidak sengaja (karena terjerat jaring). Salah satu lokasi dengan frekuensi kejadian yang tinggi yaitu di Kenjeran, Surabaya dengan 7 kali kejadian terdampar pada periode 2011-2015 (Widjajanti, 2012). Bahkan sepanjang tahun 20112013, hiu paus di wilayah Taman Nasional Teluk 
Cendrawasih ditemukan beberapa kali terperangkap jaring bagan (Direktorat Konservasi Kawasan dan di perairan Indonesia yang terjadi pada periode 2012Jenis Ikan, 2015). Informasi terdamparnya hiu paus 2017 disajikan dalam Tabel 3.

Tabel 3. Informasi terdamparnya hiu paus di perairan Indonesia (2012-2017) Table 3. Information whale sharks stranding in Indonesian waters (2012-2017)

\begin{tabular}{|c|c|c|c|c|c|}
\hline $\begin{array}{l}\text { Lokasi } \\
\text { Location }\end{array}$ & $\begin{array}{l}\text { Periode } \\
\text { Period }\end{array}$ & $\begin{array}{l}\text { Jenis Kasus } \\
\text { Type of Case }\end{array}$ & $\begin{array}{c}\text { Jumlah (ekor) } \\
\text { Number } \\
\text { (individual) }\end{array}$ & $\begin{array}{l}\text { Keterangan } \\
\text { Information }\end{array}$ & $\begin{array}{l}\text { Sumber } \\
\text { Sources }\end{array}$ \\
\hline $\begin{array}{l}\text { Bantul, } \\
\text { Yogyakarta }\end{array}$ & Mei-Juli 2012 & Terdampar & 2 & Dikubur & $\begin{array}{l}\text { Media } \\
\text { elektronik } \\
\text { Liputan } 6\end{array}$ \\
\hline $\begin{array}{l}\text { Muara Gembong, } \\
\text { Bekasi }\end{array}$ & Juli 2012 & Terdampar & 1 & $\begin{array}{l}\text { Panjang total } 12 \\
\text { m. Bangkai } \\
\text { ditenggelamkan di } \\
\text { Kep. Seribu }\end{array}$ & $\begin{array}{l}\text { Media } \\
\text { elektronik }\end{array}$ \\
\hline $\begin{array}{l}\text { Bantul, } \\
\text { Yogyakarta }\end{array}$ & Agustus 2012 & Terdampar & 1 & $\begin{array}{l}\text { Panjang } 13 \mathrm{~m} . \\
\text { Dikubur }\end{array}$ & $\begin{array}{l}\text { Media } \\
\text { elektronik } \\
\text { Liputan } 6\end{array}$ \\
\hline Garut, Jawa Barat & $\begin{array}{c}\text { September } \\
2012\end{array}$ & Terdampar & 1 & $\begin{array}{l}\text { Panjang 12-15 m. } \\
\text { Mati }\end{array}$ & Merdeka.com \\
\hline Selat Madura & Oktober 2013 & Terjerat jaring & 2 & $\begin{array}{l}\text { Mati. Konsumsi } \\
\text { masyarakat lokal }\end{array}$ & $\begin{array}{l}\text { Media } \\
\text { elektronik } \\
\text { Liputan } 6\end{array}$ \\
\hline $\begin{array}{l}\text { Pantai Anakan, } \\
\text { Painan }\end{array}$ & Januari 2015 & Terdampar & 1 & $\begin{array}{l}\text { Panjang } 5 \text { m. } \\
\text { Upaya } \\
\text { diselamatkan, } \\
\text { namun gagal. } \\
\text { Mati }\end{array}$ & JPNN.com \\
\hline Nusa Penida, Bali & Maret 2015 & $\begin{array}{l}\text { Luka akibat } \\
\text { baling-baling } \\
\text { kapal }\end{array}$ & 2 & Mati & $\begin{array}{l}\text { ANTARA News, } \\
\text { Liputan } 6\end{array}$ \\
\hline $\begin{array}{l}\text { Pantai Brencong, } \\
\text { Kebumen }\end{array}$ & Juni 2015 & Terdampar & 1 & $\begin{array}{l}\text { Panjang 4-5 m. } \\
\text { Dikonsumsi } \\
\text { masyarakat lokal }\end{array}$ & $\begin{array}{l}\text { Kebumen } \\
\text { express }\end{array}$ \\
\hline $\begin{array}{l}\text { Pantai } \\
\text { Bojongsalawe, } \\
\text { Pangandaran }\end{array}$ & Agustus 2015 & Terdampar & 1 & $\begin{array}{l}\text { Panjang } 4 \text { m. } \\
\text { Upaya dilakukan } \\
\text { dengan } \\
\text { mendorong ke } \\
\text { tengah laut } \\
\text { namun tidak } \\
\text { berhasil karena } \\
\text { tidak ada } \\
\text { sarana/alat } \\
\text { pembantu }\end{array}$ & Sindonews.com \\
\hline $\begin{array}{l}\text { Pinrang, Sulawesi } \\
\text { Selatan }\end{array}$ & Oktober 2015 & Terdampar & 1 & $\begin{array}{l}\text { Panjang } 7 \text { m. } \\
\text { Dikubur }\end{array}$ & $\begin{array}{l}\text { https://dediniblo } \\
\text { g.wordpress.co } \\
m\end{array}$ \\
\hline $\begin{array}{l}\text { Minahasa } \\
\text { Selatan, Sulawesi } \\
\text { Utara }\end{array}$ & April 2016 & Terjerat jaring & 1 & Panjang $5 \mathrm{~m}$ & $\begin{array}{l}\text { www.mongabay } \\
\text {.co.id }\end{array}$ \\
\hline $\begin{array}{l}\text { Tanggamus, } \\
\text { Lampung }\end{array}$ & Juli 2016 & Terdampar & 1 & $\begin{array}{l}\text { Panjang 5-6 m. } \\
\text { Dikubur }\end{array}$ & Harian Pilar \\
\hline $\begin{array}{l}\text { Pangandaran, } \\
\text { Jawa Barat }\end{array}$ & $\begin{array}{l}\text { Desember } \\
2016\end{array}$ & Terdampar & 1 & $\begin{array}{l}\text { Panjang 5-6 m. } \\
\text { Bobot : } \pm 1 \text { ton. } \\
\text { Dimanfaatkan } \\
\text { masyarakat lokal } \\
\text { untuk konsumsi }\end{array}$ & $\begin{array}{l}\text { Media } \\
\text { elektronik } \\
\text { Liputan 6.com }\end{array}$ \\
\hline Buleleng, Bali & Januari 2017 & Terdampar & 1 & $\begin{array}{l}\text { Panjang 5-6 m. } \\
\text { Mati }\end{array}$ & Antara news \\
\hline Ampenan, NTB & Februari 2017 & Terjerat jaring & 1 & $\begin{array}{l}\text { Panjang } 5 \mathrm{~m} \text { lebar } \\
1,1 \mathrm{~m} \text {. Mati }\end{array}$ & $\begin{array}{l}\text { kicknews. } \\
\text { Mataram }\end{array}$ \\
\hline
\end{tabular}




\section{CARA PENANGANAN HIU PAUS YANG TERDAMPAR}

Pada umumnya hiu paus terdampar terjadi di wilayah perairan yang dangkal. Hal ini diduga karena pada saat air laut pasang hiu paus berada di sekitar perairan dekat muara atau pantai untuk mencari makan, namun kemudian terjebak saat air laut surut. Pada kasus terdamparnya hiu paus seperti ini, biasanya sulit untuk dilakukan penyelamatan karena kondisi lapangan, terbatasnya peralatan dan pengetahuan tentang cara yang tepat dan cepat untuk menangani atau menyelamatkan biota tersebut. Adapun untuk hiu paus yang terjerat jaring biasanya relatif lebih mudah untuk diselamatkan. Koordinasi antara instansi terkait dan masyarakat dalam menangani dan menyelamatkan hiu paus yang terdampar maupun terjerat jaring saat ini sudah berjalan dengan baik. Tim penyelamatan hiu paus sudah terbentuk di bawah koordinasi Direktorat Jenderal Pengelolaan Ruang Laut yang bekerja sama dengan Badan Riset dan Sumber Daya Manusia Kelautan dan Perikanan, Pemerintah Daerah, Lembaga Swadaya Masyarakat (nasional dan internasional), aparat setempat, sukarelawan, dan masyarakat. Jika terjadi hiu paus terdampar dalam kondisi sudah mati, masyarakat yang mengetahui segera melaporkan kepada instansi pemerintah (Dinas Kelautan dan Perikanan Kota/Kabupaten) setempat.

Dari berbagai pengalaman dalam penanganan hiu paus yang terdampar di perairan Indonesia, dapat direkomendasikan agar:

1. Masyarakat nelayan sebaiknya tidak menyentuh tubuh hiu paus yang sudah mati sebelum ada petugas dari instansi pemerintah datang ke lokasi. Hal ini untuk menghindari kemungkinan terjangkitnya bakteri atau virus yang ada pada tubuh ikan paus ke tubuh manusia.

2. Hiu paus yang terjaring oleh nelayan dalam kondisi mati, sebaiknya nelayan tidak boleh memperjualbelikan hiu paus tersebut dikarenakan hiu paus yang mati mengandung banyak sekali virus, bakteri dan logam mercuri yang sangat tinggi sehingga tidak dapat dikonsumsi oleh manusia. Biarkan hiu paus tersebut tetap dalam jaring dan segera hubungi pihak yang berwenang untuk melakukan tindakan selanjutnya.

3. Hiu paus yang terjaring oleh nelayan dalam kondisi masih hidup, diharuskan agar nelayan segera melepaskan jeratan jaring atau benda apapun yang menjeratnya, dan jika hal tersebut tidak memungkinkan maka dapat menggiringnya atau mengarahkan hiu paus tersebut kembali ke perairan yang lebih dalam. Untuk alat tangkap yang rusak akibat robekan, untuk melepaskan hiu paus tersebut dari jeratan jaring nelayan, akan diberikan kompensasi yang sewajarnya dari pihak pemerintah.

4. Papan informasi tentang pentingnya perlindungan terhadap hiu paus dipasang di pantai-pantai di mana hiu paus sering muncul di perairan sekitar pantai. Pemasangan papan informasi bermanfaat bagi masyarakat untuk menjaga keberadaan hiu paus, yang dapat dimanfaatkan melalui pengembangan pariwisata bahari berbasis hiu paus.

5. Pelatihan khusus tentang penanganan hiu paus yang terdampar perlu dilakukan kepada nelayan di beberapa daerah di Indonesia.

6. Hiu paus yang terdampar berukuran besar dalam kondisi mati dan tidak memungkinkan untuk dilakukan penguburan maka tindakan yang tepat adalah dengan membakar tubuh hiu paus tersebut di lokasi terbuka.

7. Hiu paus dalam kondisi mati sebelum dilakukan penguburan atau pembakaran sebaiknya dilakukan pencatatan data dan informasi terhadap lokasi dan waktu terdampar, pengukuran panjang total, jenis kelamin (jika jantan dilakukan pengukuran panjang dan kondisi klasper), pengambilan sampel daging untuk analisa genetika, jika memungkinkan pengambilan tulang punggung untuk analisa umur hiu paus.

\section{UPAYA PEMANFAATAN EKOWISATA HIU PAUS DI INDONESIA}

Kepulauan Indonesia sebagai wilayah perairan yang strategis dan menjadi alur migrasi hiu paus. Beberapa wilayah perairan bahkan menjadi habitat hiu paus yang sesuai untuk mendukung kelangsungan hidupnya. Pemanfaatan ekowisata hiu paus di perairan Indonesia ditujukan pada kelompok hiu paus hidup yang mendiami habitat perairan tertentu baik yang bersifat sementara maupun menetap.

Pemanfataan ekowisata hiu paus dapat dilakukan melalui pengembangan ekowisata bahari. Dari berbagai telaah literatur dan informasi dapat disarikan beberapa tahapan yang perlu dilakukan adalah seperti berikut:

1. Melakukan identifikasi wilayah perairan tentang keberadaan hiu paus, apakah kelompok hiu paus berada dalam waktu lama atau hanya sementara.

2. Jika keberadaan kelompok hiu paus di wilayah perairan tertentu dalam waktu lama maka dapat diusulkan perairan tersebut sebagai kawasan perairan yang perlu dilindungi.

3. Pemerintah daerah dapat menetapkan kawasan perairan tersebut menjadi kawasan ekowisata hiu paus. 
4. Dalam mengelola kawasan ekowisata hiu paus pemerintah daerah harus mengacu pada buku pedoman ekowisata hiu paus yang diterbitkan oleh Kementerian Kelautan dan Perikanan.

\section{KESIMPULAN DAN REKOMENDASI Kesimpulan}

Sumber daya hiu paus dapat dimanfaatkan sebagai obyek wisata laut melalui kemunculannya di permukaan air. Di beberapa lokasi, keberadaan hiu paus sudah ada yang dimanfaatkan sebagai kawasan rekreasi atau wisata laut melihat hiu paus. Sejauh ini ketersediaan data dan informasi tentang status populasi dan pola migrasi hiu paus masih terbatas untuk dapat mengelolanya secara baik. Hiu paus merupakan biota perairan langka yang dilindungi oleh peraturan perundang-undangan sehingga sangat perlu dijaga kelestariannya. Sebagai informasi penting bahwa kemunculan hiu paus di beberapa perairan pesisir di Indonesia karena biota ini berupaya untuk mencari makanan dan diduga terjadinya perubahan iklim.

Kasus yang sering terjadi terkait dengan keberadaan hiu paus di perairan Indonesia adalah terdampar atau terjeratnya hiu paus dengan jaring ikan yang dapat menyebabkan kematian, sehingga perlu adanya upaya-upaya penanganan yang tepat dan benar. Penanganan hiu paus terdampar dan terjerat jaring saat ini dilakukan oleh berbagai instansi pemerintah, lembaga swadaya masyarakat, dan masyarakat umum.

\section{Rekomendasi}

1. Hiu paus berada di wilayah perairan Indonesia, yang secara peraturan perundangan-undangan telah dilindungi. Biota laut ini dapat dimanfaatkan sebagai obyek wisata atas kemunculannya di permukaan. Namun, sejauh ini belum diketahui jumlah populasi dan pola penyebarannya di perairan Indonesia, termasuk pendataan dan evaluasi untuk memberikan solusi penyebab terjaring dan atau terdamparnya hiu paus di perairan Indonesia. Sehubungan dengan itu perlu dilakukan pemantauan pergerakan hiu paus untuk mengetahui perkembangan populasinya. Kegiatan pemantauan hiu paus dapat dilakukan melalui kerja sama antara instansi pemerintah, penyelenggara penelitian dan pengembangan, pergurunan tinggi, dan lembaga swadaya masyarakat.

2. Terdapatnya beberapa wilayah perairan yang menjadi habitat sementara maupun menetap hiu paus merupakan aset yang dapat meningkatkan pendapatan daerah, sehingga perlu dikembangkan wilayah perairannya sebagai ekowisata bahari dengan melibatkan peran pemerintah daerah, instansi terkait, lembaga swadaya masyarakat, dan pemberdayaan masyarakat lokal.

3. Melakukan penanganan hiu paus terdampar atau terjerat jaring melalui koordinasi antar instansi terkait dan pelibatan masyarakat.

4. Untuk keperluan penelitian, perlu dilakukan pengambilan sampel tulang punggung $(5-10 \mathrm{~cm})$ dari hiu paus terdampar sebelum dimusnahkan/ dikubur, bertujuan untuk mengetahui umur. Selain itu dilakukan pengukuran panjang total, dan pengukuran panjang klasper untuk mengetahui tingkat kematangan kelamin jantan.

\section{PERSANTUNAN}

Tulisan ini merupakan hasil kegiatan Kajian Kebijakan Pemulihan Habitat dan Konservasi Sumber Daya Ikan yang didanai dari APBN tahun 2017 yang dilaksanakan oleh Pusat Riset Perikanan - Badan Riset dan SDM Kelautan dan Perikanan, dibawah kelompok penelitian kebijakan konservasi sumber daya ikan dan pemulihan habitat. Penulis mengucapkan terima kasih kepada Dinas Perikanan dan Kelautan Probolinggo dan Situbondo dan beberapa kelompok nelayan yang melakukan monitoring kemunculan hiu paus di dua lokasi tersebut yang telah membantu kelancaran pelaksanaan penelitian ini. Penulis (Budi Nugraha, Dharmadi, dan Ngurah N. Wiadnyana) merupakan kontributor utama.

\section{DAFTAR PUSTAKA}

Anderson, R.C., \& Ahmed, H. (1993). Shark fisheries of the Maldives. Ministry of Fisheries and Agriculture, Maldives, and FAO, Rome.

Brooks, K., Rowat, D., Pierce, S.J., Jouannet, D., \& Vely, M. (2010) Seeing spots: Photo-identification as a regional tool for whale shark identification. Western Indian Ocean Journal of Marine Science. 9 (2), 185-194.

Brunnschweiler, J.M., Baensch, H., Pierce, S.J., \& Sims, D.W. (2009). Deep-diving behaviour of a whale shark Rhincodon typus during long-distance movement in the Western Indian Ocean. Journal of Fish Biology. 74(3), 706-714. https://doi.org/ 10.1111/j.1095-8649.2008.02155.x.

Clarke, E., \& Nelson, D.R. (1997). Young whale sharks, Rhincodon typus, feeding on a copepod bloomnear La Paz, Mexico. Environmental Biology of Fishes. 50, 63-73. https://doi.org/10.1023/ A:1007312310127. 
Colman, J.G. (1997). A review of the biology and ecology of the whale shark. Journal of Fish Biology. 51(6), 1.219-1.234. https://doi.org/10.1111/ j.1095-8649.1997. tb01138.x.

de la Parra Venegas, R., Hueter, R., González, C.J., Tyminski, J., Remolina, J.G., Maslanka, M., Ormos, A., Weigt, L., Carlson, B., \& Dove, A. (2011). An unprecedented aggregation of whale sharks, Rhincodon typus, in Mexican coastal waters of the Caribbean Sea. PLoS ONE. 6: e18994.

Direktorat Konservasi Kawasan dan Jenis Ikan. (2015). Pedoman umum monitoring hiu paus di Indonesia. Direktorat Jenderal Kelautan, Pesisir dan PulauPulau Kecil. Kementerian Kelautan dan Perikanan. Jakarta. 48 hal.

Eckert, S.A., \& Stewart, B.S. (2001). Telemetry and satellite tracking of whale sharks, Rhincodon typus, in the Sea of Cortez, Mexico, and the North Pacific Ocean. Environmental Biology of Fishes. 60(1-3), 299-308. https://doi.org/10.1023/ A:1007674716437.

Hasan, A., \& Sianipar, A. (2019). Monitoring populasi Hiu Paus (Rhincodon typus) di perairan Kaimana, Provinsi Papua Barat. Laporan Teknis CI Indonesia. 10 hal.

Handoko, K., Sukmoputro, R.A.I., Himawan, M., \& Tania, C. (2018). Pola kemunculan Hiu Paus (Rhincodon typus) di Perairan Botubarani, Gorontalo. BPSPL Makassar. https://kkp.go.id/ bpsplmakassar/artikel/5797-pola-kemunculan-hiupaus-rhincodon-typus-di-perairan-botubaranigorontalo-2018. doi:10.3354/meps215275.

Himawan, M.R. (2017). Komposisi hiu paus berdasarkan jenis kelamin, ukuran, perilaku kemunculan serta ancaman keberadaannya di perairan Indonesia. Tesis. Sekolah Pascasarjana. Institut Pertanian Bogor. 47 hal.

Himawan, M.R., Tania, C., Fadela, S.N., \& Bramandito, A. (2017). Final report: Whale Shark Indonesia Project. Whale Shark Indonesia Project, Bogor Agricultural University, WWF-Indonesia. 30 pp.

Himawan, M.R., Tania C, Noor B.A., Wijonarno A., Subhan B., \& Madduppa, H. (2015). Sex and size range composition of whale shark (Rhincodon typus) and their sighting behaviour in relation with fishermen lift-net within Cenderawasih Bay National Park, Indonesia. AACL Bioflux. 8(2), 123-133.
Himawan, M.R. (2014). Komposisi hiu paus berdasarkan jenis kelamin dan ukuran serta perilaku kemunculannya di kawasan Taman Nasional Teluk Cenderawasih. Skripsi. Departemen Ilmu dan Teknologi Kelautan, Fakultas Perikanan dan IImu Kelautan, Institut Pertanian Bogor. 22 hal.

Hueter, R.E., Tyminski, J.P., \& de la Parra, R. (2013). Horizontal movements, migration patterns, and population structure of whale sharks in the Gulf of Mexico and Northwestern Caribbean Sea. PLoS ONE 8(11), 10.1371. https://doi.org/10.1371/ annotation/491b9b6c-7f77-4fb0-b336572078 aec830.

Keputusan Menteri Kelautan dan Perikanan RI No. 18/KEPMEN-KP/2013 tentang Penetapan Status Perlindungan Penuh Ikan Hiu Paus (Rhincodon typus).

Ketchum, J.T., Galva 'n-Magan a, F., \& Klimley, A.P. (2012). Segregation and foraging ecology of whale sharks, Rhincodon typus, in the southwestern Gulf of California. Environmental Biology of Fishes. 96(6), 779-795. DOI:10.1016/bs.amb.2019.08.005.

McKinney, J.A., Hoffmayer, E.R., Wu, W., Fulford, R., \& Hendon, J.M. (2012). Feeding habitat of the whale shark Rhincodon typus in the northern Gulf of Mexico determined using species distribution modelling. Mar. Ecol. Prog. Ser. 458, 199-211. doi:10.3354/meps09777.

Putra, M.I.H., \& Lewis, S. (2017). Laporan Tahunan Program Penelitian dan Konservasi Megafauna Laut di Perairan Solor Periode 2015-2016. Yayasan Misool Baseftin. Misool Foundation. 60 hal.

Noviyanti, N.S., Kamal, M.M., \& Wardiatno, Y. (2015). Kemunculan Hiu Paus (Rhincodon typus), di Pesisir Kabupaten Probolinggo Jawa Timur. Prosiding Simposium Hiu dan Paus di Indonesia: 115-119.

Pierce, S.J., \& Norman, B. (2016). Rhincodon typus. IUCN Red List of Threatened Species 2016. http:/ /dx.doi.org/10.2305/IUCN.UK.2016-1.

Riley, M.J., Hale, M.S., Harman, A., \& Rees, R.G. (2010) Analysis of whale shark Rhincodon typus aggregations near South Ari Atoll, Maldives Archipelago. Aquatic Biology. 8, 145-150. https:// doi.org/10.3354/ab00215 
Robinson, D.P., Jaidah, M.Y., Jabado, R.W., LeeBrooks, K., Nour El-Din, N.M., \& Malki, A.A.A. (2013). Whale sharks, Rhincodon typus, aggregate around offshore platforms in Qatari Waters of the Arabian Gulf to feed on fish spawn. PLoS ONE 8(3), e58255. https://doi.org/10.1371/ journal.pone.0058255.

Rowat, D., Brooks, K., March, A., McCarten, C., \& Jouannet, D. (2011) Longterm membership of whale sharks (Rhincodon typus) in coastal aggregations in Seychelles and Djibouti. Marine and Freshwater Research. 62, 621. https://doi.org/ 10.1071/MF10135.

Rowat, D., \& Gore, M. (2007). Regional scale horizontal and local scale vertical movements of whale sharks in the Indian Ocean off Seychelles. Fisheries Research. 84, 32-40. doi:10.1016/ j.fishres.2006.11.009.

Sianipar, A. (2019). Kegiatan konservasi Hiu Paus (Rhincodon typus) Cl Indonesia di Taman Nasional Teluk Cendrawasih tahun 2018-2019. Laporan Teknis Cl Indonesia. 20 hal.

Squeira, A.M.M., Mellin, C., Meekan, M.G., Sims, D.W., \& Bradshaw, C.J.A. (2013). Inferred global connectivity of whale shark Rhincodon typus populations. Journal of Fish Biology. 82(2), 367389. https://doi.org/10.1111/jfb.12017.

Stewart, B.S., \& Wilson, S.G. (2005). Threatened fishes of the world: Rhincodon typus (Smith 1828) (Rhincodontidae). Environmental Biology of Fishes. 74, 184-185. https://doi.org/10.1007/ s10641-005-2229-1

Syah, A.F., Musrifah., \& Cahyono, H. (2018). Pemodelan daerah potensial kemunculan hiu paus (Rhincodon typus) menggunakan data penginderaan jauh di perairan Probolinggo, Jawa Timur. J.Lit.Perikan.Ind. 24(3), 209-216.

Tania, C. \& M.R. Himawan. (2017). Perspektif lain di balik kemunculan hiu paus di Gorontalo. www.wwf.or.id. Posted on 29 Agustus 2017.

Tania, C., Blaesbjerg, M., Himawan, M.R., Noor, B.A., Suruan, S.S., Pranata, B., \& Stewart, B.S. (2016). Characteristics of whale sharks (Rhincodon typus) in Teluk Cenderawasih National Park, Indonesia. QScience Proceedings (The 4th International Whale Shark Conference) 2016:iwsc4.62. http:// dx.doi.org/10.5339/qproc.2016.iwsc4.62

Taylor, J.G. (1996). Seasonal occurrence, distribution and movements of the whale shark, Rhincodon typus, at Ningaloo Reef, Western Australia. Marine and Freshwater Research. 47, 637-642. doi: 10.1071/MF9960637.

Weigmann, S. (2016). Annotated checklist of the living sharks, batoids and chimaeras (Chondrichthyes) of the world, with a focus on biogeographical diversity. Journal of Fish Biology, 88(3), 837-1.037. https://doi.org/10.1111/jfb.12874.

Wilson, S.G. \& Newbound, D.R. (2001). Two whale shark faecal samples from Ningaloo Reef, Western Australia. Bulletin of Marine Science. 68, 361-362.

White, W.T., \& Cavanagh, R.D. (2007). Whale shark landings in Indonesian artisanal shark and ray fisheries. Fisheries Research. 84(1), 128-131. doi:10.1016/j.fishres.2006.11.022.

Widjajanti, W. (2012). Langkah-langkah penanganan ikan hiu paus yang terdampar. www.kkp.go.id. 